\title{
HUMAN SECURITY AS AN INSTRUMENT OF (TRADITIONAL) COMPREHENSIVE SECURITY IN JAPAN, SOUTH KOREA AND TAIWAN
}

\author{
Joel Atkinson* \\ Department of Chinese Studies, Graduate School of International and Area Studies \\ (GSIAS), Hankuk University of Foreign Studies, 107 Imun-ro, Dongdaemun-gu, \\ Seoul, 02450 Republic of Korea \\ E-mail: joel.atkinson@hufs.ac.kr
}

Published online: 15 January 2018

To cite this article: Atkinson, J. 2018. Human security as an instrument of (traditional) comprehensive security in Japan, South Korea and Taiwan. International Journal of Asia Pacific Studies 14 (1): 1-25, https://doi.org/10.21315/ijaps2018.14.1.1

To link to this article: https://doi.org/10.21315/ijaps2018.14.1.1

\begin{abstract}
Japan, South Korea and Taiwan inhabit an insecure world, both objectively and in terms of how threats are perceived through historically shaped beliefs. A similar conceptualisation of "comprehensive security" forms an intellectual basis for foreign policy in all three countries. In addition to maintaining armed forces, threats are met through strengthening the national economy, and attempts to influence other states and enhance national prestige. Accordingly, the human security policies of these three countries seek comprehensive security through acquiring influence and prestige. None of the three gives substantive attention to the novel, challenging aspects of human security. This is problematic, as all three have a clear interest in the success of the key premises of the human security discourse given their precarious geopolitical situations.
\end{abstract}

Keywords: Foreign policy, security, East Asia, aid, strategic culture

\section{INTRODUCTION}

Discussion over human security is notoriously diffuse, posing a challenge when seeking to understand its role in the politics of particular countries and regions. More than 20 years after the publication of the Human Development 
Report, the debate on human security is still very much in flux. As Breslin and Christou $(2015: 1)$ note, there is significant variation in the way the term has been "constructed, received and appropriated," and the breadth of the term drives a seemingly endless debate over its usefulness (Curley 2012: 527). Yet despite this lack of agreement over what human security is, the concept continues to draw considerable governmental and intergovernmental (not to mention academic) attention. Why?

An obvious-yet key-reason is because it is useful. The term human security has been described as a fad or a catchphrase used too often and too loosely (Edström 2003: 211). Arguably, the term's indeterminateness is in part functional (Paris 2001: 88). Sometimes it plays the role of jargon, with all of the attendant social roles that entails. But it can also be put to use in more profound ways. For example, Job and Evans (2008: 364) note that the term can be used to advance harmful agendas, citing China's rhetorical justification for its repressive policies against minorities.

What makes human security a useful tool? The term human security generated initial excitement and interest where it challenged perceived "traditional" security ideas. For example, in 2001 then Secretary General of the United Nations (UN), Kofi Annan, spoke of an evolving "new understanding of the concept of security" that instead of seeking to protect national territory from external enemies, aimed to protect communities and individuals from "internal violence" (UN 2001). A new understanding was evolving, but not in the way Annan characterised. Putting aside the abstractions of International Relations theorists, real-world states (and their antecedents) have always prioritised the security of (some) human beings over territory or sovereignty (the ruler and an inner elite at a minimum) (see for example Krasner 1999). People have also long recognised the threat states pose to their citizens, and the violence that poverty does to human happiness (hence the concepts of negative and positive human rights; see for example Hershkoff (2002)). And the concept of a state (or its human constituents) having responsibilities toward non-nationals is obliviously not new either, for example see the domestic debates on the morality of imperialism in the United States at the turn of the 19th century (Healy 1970: 127). So, the novelty of human security depends on the depth and breadth that such security to people inside and outside the territory of the state is extended, not the mere recognition of its importance.

To simplify for the purposes of clarity, human security presents two main challenges in terms of this depth and breadth. First, the discourse pushes countries to extend (in breadth) some of the concern they have for their own nationals to those of other countries and the stateless. This has 
significant implications for countries neighbouring civil wars or violent, repressive regimes (e.g., the signatories to the African charter; see Kioko (2011)). But it is also a challenge to the Global North (i.e., the Organisation for Economic Co-operation and Development (OECD) members) that are (usually) geographically distant from zones of human insecurity in the South. Of course, OECD countries already display some concern for non-nationals, as demonstrated in their eschewal of war crimes and unnecessary casualties during war or in their Official Development Assistance (ODA), peacekeeping and refugee policies. Often the degree of concern appears proportional to the geographic proximity, with proximity doing much to determine national interest perceptions (Hill 2003: 170). So the novel or pointed aspect is that which pushes these states to invest their resources (including their military might and lives of their military personnel) with less regard for traditional views of national interest (or the interests of state nationals) and more regard for the interests of humanity as a whole. It is worth noting here that this could include the costs of violating or infringing on another state's sovereignty, something powerful states are willing to do where their national interests require it, such as the American raid that killed Osama bin Laden in Pakistan or the Russian takeover of Crimea (see, e.g., Berkowitz 2011; Allison 2017).

The second challenge is more pointedly directed at governments in the Global South, which are effectively being told that they should extend (in depth) better protection to their own nationals (such as those from outside the favoured ethnic or social group) or possibly face interventions of various kinds and degrees. At its pointiest and most controversial, this could be a warning to leaders that abuse their citizens that the norm of state sovereignty is now a less effective moral defence against interventions. This issue of humanitarian intervention is undoubtedly the most controversial within the human security discourse (Evans 2004: 272; Fukushima 2008: 48). However, this pressure on states in the South to extend security downward may be more invitation than coercion, and the intrusion from the North need not be violent or even unwelcome. For example, it may take the form of extra aid funding or governance training for officials.

Some countries for some periods of time and to varying degrees pushed harder in terms of these dimensions of breadth and depth. The Canadian government stands out in this regard (e.g., Suhrke 1999). In a 2002 publication, the Canadian Department of Foreign Affairs and International Trade stated that: 
Our objective is to build a world where universal humanitarian standards and the rule of law protect all people; where those who violate these standards are held accountable; and where our international institutions are equipped to defend and enforce those standards (Gilson and Purvis 2003: 195).

Notably, all of the accomplishments of the human security discourse listed by Paris (2001: 88) were achieved to a significant extent due to the participation and leadership of Canada, such as the 1997 Ottawa landmine treaty and the establishment of the International Criminal Court.

Another significant player in the human security field, Japan, has exerted perhaps even more energy in trying to define the agenda. But as will be discussed below, Japan appears to be less interested in extending security in terms of breadth and depth. Indeed, Japan appears to have been more inclined than Canada to mitigate the most novel and challenging aspects of the human security agenda.

This article aims to make a modest contribution to the literature by exploring how pre-existing priorities and concepts influenced not only this Japanese approach to human security, but that of its Northeast Asian neighbours, South Korea and Taiwan, as well. The straightforward thesis is that these three countries have adopted a similar approach to human security because they have a similar strategic culture in which the concept of comprehensive security contributes to shaping foreign policy behaviour. The role of culture in determining security policy is well established in the literature (e.g., Glenn 2009; Johnston 1995; Snyder 1977). Meyer (2006: 20) defines such "strategic culture" as the norms, ideas and patterns of behaviour shared among actors and social groups that shape security and defence goals. The possible influence of such strategic cultures are not limited to security policy, narrowly defined, and I apply this framework to place a country's human security policies in the context of its wider foreign policy.

The remainder of this article is structured as follows. The next section briefly discusses the development and content of the concept of comprehensive security. This is followed by an examination of the use of human security as a tool in the comprehensive security policies of Japan, South Korea and Taiwan. After this, the implications of these three case studies for our understanding of the human security concept in East Asia are discussed. The final section concludes and notes the risks in adopting an instrumental approach to human security in Northeast Asia. 


\section{TRADITIONAL SECURITY IN JAPAN, KOREA AND TAIWAN: COMPREHENSIVE SECURITY}

At the risk of oversimplification, it is helpful to clarify our discussion of a Northeast Asian comprehensive security approach to foreign policy by sketching the evolution of the idea of "rich nation, strong army" (富国強兵). ${ }^{1}$ This phrase originated with the ancient Chinese Legalist philosophers. In modern times from the early 19th century, it has been used by Chinese in discussions on restoring China's power (Deng and Wang 1999; Schell and Delury 2013). Meiji reformers in Japan adopted the saying as a slogan pointing the way forward to secure Japan after their exposure to Western models and ideas (e.g., Ch'en and Kowashi 1984), in particular the ideas of thinkers such as Friedrich List and their linking of economic nationalism with national security (Sheldon 2002: 97). It is worth pointing out that the Japanese iteration of the concept would influence its Korean and Taiwanese colonies, as well as the Chinese Kuomintang (KMT) government that would control the Republic of China on Taiwan after 1949 (Moore 2013: 5).

In Japan, the postwar policies that would evolve into what came to be known as comprehensive security, "drew on the Meiji idea of 'rich nation, strong army' but infused it with liberal internationalism" (Samuels 2007: 56). This concept of comprehensive security sees economic security as at least as vital as military security, with diplomacy and other policy instruments all being brought to bear in addition to the military in securing the nation (Samuels 2007: 56-57). The term "comprehensive security" would wane in use, but continued to serve as the basis and framework for Japan's security policy in subsequent decades (Kaji 2015: 55).

The policies of Korea and Taiwan have developed in a remarkably similar direction to Japan. The concept of "rich nation, strong army" resonated with the governments in Taiwan and South Korea, which faced formidable security and economic challenges of their own (see for example Cho 2008; Moran 1998; Rhyu and Lee 2006). In the case of Korea, this idea carried over to a policy of "developmental realism," that married hardnosed realism abroad to domestic developmental statism (Cho 2008). "Rich nation, strong army" remains a key pillar in Korea's strategic culture (Kim 2014).

Today, a similar conceptualisation of "comprehensive security" forms an intellectual basis for foreign policy in all three countries. For example, in 2008 the Korean government's expressed "foreign policy vision" sought to promote peace, achieve economic development and enhance national status through giving international aid (Kang 2008). And in Taiwan's ODA 
white paper (Ministry of Foreign Affairs, MOFA (Taiwan) 2009b), Foreign Minister Affairs Francisco H.L. Ou stated:

Diplomacy's primary objective is to seek to maximize a nation's interests, and ensure its survival and development. Providing aid to foreign countries forms an important part of this... (3)

This concept of comprehensive security - and the shared value orientations and beliefs that underpin it - act as a mediating factor that shapes the human security policies of Japan, Korea and Taiwan in similar directions depending on the context.

\section{HUMAN SECURITY AS A COMPREHENSIVE SECURITY TOOL IN JAPAN}

Several commentators have seen parallels between Japan's concept of comprehensive security and human security, and therefore the intrinsic "Asianess" of the human security concept (Guan 2012). Most notably, Acharya (2001: 451) argued that comprehensive security is the nearest conceptually to human security, and that comprehensive security "can claim even stronger Asian roots because it was developed by Japan." Song (2014b: 6) sees in Japan's comprehensive security both a "traditional statist notion" of military cooperation (with the US) and a "non-traditional" attention to economic, energy and food issues.

However, such a comparison must be done cautiously. First, as noted above the concept of comprehensive security developed in dialogue with Western ideas. Not only Germans like Friedrich List but Americans such as Alfred Thayer Mahan also stressed the economic aspects of national security, and influenced Japanese thinking (see, e.g., Yoshihara and Holmes 2006: 27-30). Japan's postwar leaders inherited an insecure, competitive worldview from imperial Japan, as well as expectations of elite strategising and vigorous external activity to secure the nation. This meant that the decision to not (re-) build up the military had to be justified; if elites were not going to secure the nation through the military, then how were they going to do it? This securitised aspects of the policy discourse that most other advanced countries did not feel the need to subsume under the rubric of a unified "security policy." So diplomacy, investment, ODA and so on were viewed as tools - wielded by elites - to secure the Japanese nation. Obviously, this kind of elite-led 
nationalism is very different from the progressive aspects of human security discussed above.

The human security normative discourse has done little to move Japan beyond this traditional posture. Japan has a long tradition of valuing the security of people belonging to what the elites considered the "Japanese nation." Akami (2006: 162) argues that within this discourse, rather than as individuals, the "Japanese people" are defined collectively and identified as belonging to a homogenous national society. Also, as noted above, there is a long-held policy of reaching out to influence the world through ODA and diplomacy. Hence, Kaji (2015) can find an espousal of what she considers human security ideas in Japan's 1946 constitution. Rather than seeing human security as an aim in-of-itself and moving to appreciably extend human security within Japan or aboard, human security has been seen largely as a tool to continue to pursue pre-existing domestic and global aims. The policy stakes are not low: contributing to the comprehensive security of the Japanese nation, and the legitimacy of the Japanese state both domestically and internationally (Gilson and Purvis 2003: 193-194; 200).

Japan was one of the few states that quickly adopted the term human security after the landmark 1994 UNDP report was released (Kaji 2015: 48). According to Edström (2003: 213), a reason for Japan's interest was the impact of the Asian currency crisis on regional perceptions of security.

However, again, it would be a mistake to overstate actual conceptual changes. A far more salient crisis driving these changes was what policymakers perceived to be Japan's declining influence. The Japanese government saw an opportunity to leverage human security into increased international status (Ho 2008: 103).

An initial trigger for this policy was the 1990-1991 Gulf War. Japan provided financial support rather than troops for the US-led coalition, a move which was derided as chequebook diplomacy (Hughes and Krauss 2007). The trauma of this episode drove Japan do better in terms of its contribution to international security (Ho 2008: 102; Kaji 2015: 55). According to Evans (2004: 271) human security was seen as a way to put a more "compassionate face" on its existing aid program while at the same time playing a more proactive role in international security in a way that would not alter its alliance relationship with the US or necessitate a change in Japan's constitution. This is in contrast somewhat to the Canadian government, which has been criticised for using the human security discourse to make Canadian ODA more self-interested through securitisation, undermining the ethical rational for development assistance (Brown 2016: 121). 
The next major spur was the failure to secure an expanded United Nations Security Council (UNSC) with an anticipated permanent non-veto seat for Japan. This difficulty and the poor showing of Japanese candidates in elections for executive positions in major international organisations caused Japan's UN Ambassador Kenzo Oshima to express concerns over Japan's declining international status and influence (Ho 2008: 102). According to Ho (2008: 103), Japan saw the human security discourse as a means to win a UN Security Council permanent seat as a promoter of international norms.

For the most part, the Japanese government focused on changing foreign perceptions of its policies rather than changing the substance. According to Ho (2008: 103), human security allowed Japan to demonstrate its strong support for international security without requiring the use of its armed forces, and in a way consistent with pre-existing aid policy. Carvalho and Potter (2016: 89) described the emergence of the concept of human security as a "godsend" for Japanese policymakers, as it allowed Japan to claim a greater contribution to maintaining international security through the existing foreign policy doctrine.

This meant that Japan's human security discourse would be laid over the top of existing policies. It would also be done in a way that allowed Japan play a larger role without alarming its neighbours or its own public (Lam 2006: 143). In the early 1990s, before the global human security discourse took off, Japan had already identified global issues, democracy, human rights, poverty reduction, and sustainable development as important parts of its policy (Kaji 2015). Japan's conception of human security grew out of its development assistance policies. It was very important to the Japanese government that the use of force was not included in its concept of human security (Ho 2008: 104).

Like its aid policy, this human security policy would be win-win. It would provide more comprehensive security for the Japanese state (and "nation") and more comprehensive security for its partner states. In Acharya's formulation (2001: 453-454), comprehensive security expanded the breadth of state security threats, while human security expanded the breadth of security referents, with a focus on justice and emancipation. So for Acharya, the comprehensive security framework must be "reworked and extended vertically" to protect (sub-national) individuals and communities if it is to be synergic with the new concept of human security. However, for the most part, Japan would not rework and extend its conception of security vertically. Rather, if aspects of the human security discourse undermined its comprehensive security or that of its foreign government partners, then those aspects would be resisted or subverted. 
So, Japan's human security is a balance between three, often opposing, goals: 1) to be as high profile as possible with Western countries; 2) to not challenge or offend developing country governments; and 3) oppose human security developing as a norm that would oblige Japan to change its policies (and increase protections for non-nationals) or isolate Japan if it did not change its policies.

Key to making this balancing act work was to neutralise the part of the human security discourse focused on Northern interventions to protect people from fear in the South. The Japanese government made a concerted effort to promote the broad version of the concept. And, it criticised undue focus on freedom from fear as opposed to freedom from want (Evans 2004: 270; Acharya 2001: 446). Japan's approach was welcomed by Asia-Pacific governments wanting to distance human security from human rights and humanitarian intervention (Acharya 2001: 447-448). So while Canadian scholars and policy makers viewed the "Responsibility to Protect (RtoP)" as part of the human security agenda, their Japanese counterparts sought to separate RtoP and human security as complimentary yet distinct agendas (Curley 2012: 534).

Japan was largely responsible for establishment of the "commission on human security" which wrote the report Human Security Now (Kaji 2015: 48). The report prioritised the "freedom from want" dimension and eschewed discussion of the issue of humanitarian intervention. The commission also stated that the idea of human security complemented state security and did not conflict with the sovereignty principle (Ho 2008: 106).

However, even within the "freedom from want" domain, the report pushed the agenda away from increasing Japan's responsibilities. The major thrust was that human security is not just about poverty, but "downward risks" such as currency crises and natural disasters (Kaji 2015: 48). These are areas directly impinging on the human security of Japanese nationals and that are already a high priority for Japan. They are also areas in which Japan would like to assume more leadership.

In short, there is surprisingly little substance to Japan's human security policy. Japan has invested considerable effort in mainstreaming the concept and bringing opposing parties together in consensus definitions (Kaji 2015). And Edström (2003: 217) wryly points out that organising conferences is "a key undertaking for Japan in its efforts to promote human security." However, Japan's human security policy yields few concrete results. Aid effort has remained below the DAC average (Atkinson 2017: 257). Domestic efforts to empower NGOs and protect marginalised groups such as victims of human 
trafficking or refugees remain poor (Gilson and Purvis 2003; Ho 2008). According to Sachi Takay, to date, the government still does not view irregular migrants in Japan as a vulnerable group to be protected. Rather they are usually seen as a threat (Takay 2014: 23). So, while the Japanese government has represented human security as "one of the important pillars of Japan's foreign policy" (Takay 2014: 23), Kaji (2015: 54), a veteran of Japan's MOFA and sympathetic to Japanese policy, can note only the promotion of universal health coverage and the renaming of small grassroots projects that began in 1989 as examples of Japan "implementing human security."

It is also important to note that the most significant policy change, involvement in UN peacekeeping and US military efforts has little to do with the normative power of human security. Rather, it was pressure from the US and domestic forces pushing Japan toward a more normal military that was key. Under Koizumi, Japan transformed itself into a more willing and active US ally. After the 9/11 terrorist attacks, Japan dispatched forces to provide non-combat logistical and reconstruction support in Afghanistan and Iraq. This came along with many other steps to normalise Japan (Hughes and Krauss 2007: 158). The term human security served as a useful umbrella that could bridge the existing policies of providing ODA and engaging with regional states on non-traditional security issues, with the growing use of Japan's armed forces abroad. According to Oros (2017: 1), this "security renaissance" driven by new power realities in the region - not human security discourses-is now at the point that "Japan is back" in terms of military security. Interestingly, Japanese Prime Minister Shinzo Abe's attempts to check rising Chinese influence (a quintessential traditional security issue) has involved adopting democracy and human rights-related values-based diplomacy (Hughes 2015: 80-81).

\section{HUMAN SECURITY AS A COMPREHENSIVE SECURITY TOOL IN KOREA}

Conceptually, the reaction of Korean policymakers to the human security discourse is remarkably similar to those of their Japanese counterparts. However, there are major differences in terms of interests, and this took Korea's human security policy in a somewhat different direction.

In particular, Korea is not under the same pressure as Japan to recast itself as a security actor. A clear example is Korea's contribution of a 154-member medical team to the Gulf War. This was the first major deployment since large scale involvement in fighting on side of the US in the Vietnam War. This Gulf 
War deployment was lauded despite its small size and non-combat role (Bridges 1992). In the post-Cold War era, Korea would increase its involvement in peacekeeping and make significant contributions to the US' military efforts in Iraq and Afghanistan (Bowers 2014). Moreover, Korea arguably plays a major security role in the eyes of the US and its allies simply by maintaining its heavily armed face off with North Korea. In addition, unlike Japan, Korea has no pretensions on creating a permanent seat for itself at the UNSC. These differences in interests mean Korea has significantly less need to propagate the term human security or put itself at the centre of international discussions on the concept. Hence, it is not surprising that Kim, Bae and Shin (2015: 1) found that the Korean government rarely uses the term "human security."

Nevertheless, in common with Japan, Korea clearly uses human security instrumentally in the service of pre-existing concepts. Job and Evans (2008: 364) see Korea as embodying the region's "most liberal, or 'liberating', notion of human security" focused on "alleviating the humanitarian and political plight of North Korea's citizens." However, the notion of helping North Koreans clearly predates and overshadows human security within Korean policy thinking. So rather than being simply a "notion" as Job and Evans describe it, human security is a label applied to a more important, hierarchically higher, "notion" of helping North Koreans. And whether or not policies toward North Korea constitute human security policy is complicated by the fact that - in the minds of at least some South Koreans - the people of both Koreas belong to the name "nation." Under the South Korean constitution, North Koreans automatically become citizens after transitioning through a process of interrogation and settlement programmes (Song 2014a: 149-150). As discussed above, the impulse to secure one's own nation is quite different from what makes human security novel and accepting North Korean defectors or refugees is as old as the division of the peninsula itself.

It is also important to note that President Kim Dae Jung's policies that Job and Evans (2008: 365) saw as transforming South Korean policies towards the North from a traditional paradigm to a human security one would segue into a more hard-line approach in subsequent administrations. According to Grundy et al. (2012), such a hard-line approach constitutes a failure to protect the interests of women and children in North Korea. In sum, it is not at all clear what Korea's policy toward the North tells us about its approach to human security.

Tellingly, Korea is much less willing to talk about freedom from fear outside of the context of North Korea. For example, in stark contrast to its promotion of its economic development success, Korea does not take active 
measures to promote its achievements in democracy, human rights and the rule of law as it does not want to create friction with ODA recipient governments (Lee 2015: 1). Like Japan, Korea uses the term "human security" as a label for its various foreign policy activities and to signal that it is an authoritative international actor. For example, MOFA used the term "human security" in policy documents in reference to broader discussions on foreign policy, and President Park Geun-hye used the term in public speeches in reference to overall foreign policy goals (Kim, Bae and Shin 2015: 14). Foreign Minister Yun Byung-se stated that the global policies of the Park Administration "reflect the belief that peace and prosperity of South Korea and the world are indivisible, and that there has been a global paradigm shift which emphasizes the importance of human security" (Kim, Bae and Shin 2015: 14). Korea is a country whose peace and prosperity is indivisible from the world more than most, due to its reliance on the US (and increasingly China) for security and its export dependence. It is not likely that the human security discourse has done much to further sensitise Korea to such linkages. Rather than a paradigm shift, the minister is actually responding to a rhetorical shift, one that Korea feels compelled to follow.

There has also been some rebranding of ODA as human security activity. Kim, Bae and Shin (2015: 14) found that MOFA and its Korea International Cooperation Agency (KOICA) use the term in relation to ODA, but not the more powerful and influential Ministry of Strategy and Finance (MOSF) and its Economic Development Cooperation Fund (EDCF). Like Japan, the Korean government's engagement with the human security discourse is superficial. According to Kim, Bae and Shin (2015: 14), civil society actors in Korea doubt whether ODA activities reflect human security.

Again, in common with Japan, Korea uses the term as a label for nontraditional security (NTS) threats, most importantly terrorism, environmental degradation, transnational crime, internal conflict, poverty, and disasters. And it considers APEC meetings on these types of threats as "human security" activities (MOFA (Korea) 2008). Particularly important was the outbreak of the MERS virus in 2015. The outbreak caused considerable public concern and negatively affected the tourism industry. The government received considerable public criticism for its response. The term human security was used by the government to signal it as a major priority that requires cooperation with official foreign actors, and to justify government mobilisation and force better cross-government cooperation. 


\section{HUMAN SECURITY AS A COMPREHENSIVE SECURITY TOOL IN TAIWAN}

Taiwan's initiation into the human security discourse was somewhat slower and more hesitant than Japan or Korea (Evans 2004: 269). Evans (2004: 271) states that unlike new democracies Thailand, South Korea, and the Philippines, "In Taiwan, where there is a strong civil society and functioning democratic institutions, the concept is only just beginning to get attention." In a subsequent publication with Job, Evans (2008: 369) argued that Taiwan's focus on "hard security agendas" has hampered the development of a human security perspective. Kuo Kuo-wen (2010), a high ranking official ${ }^{3}$ in one of Taiwan's two main political parties, agrees that compared to many countries, Taiwan, whether in terms of academia, government or the public, has little experience promoting the concept. There is also a continuing undercurrent of cynicism toward the debate (e.g., Tan 2016).

However, beneath the surface there are remarkable similarities in Taiwan's approach with that of the other two countries. And in common with Japan and Korea, Taiwan almost reflexively views human security through the prism of how it relates to Taiwan's comprehensive security. For example, Kuo Kuo-wen (2010) states that in Taiwan human security is regarded as part of comprehensive national security, with mainstream thinking still placing the "state" (guo 國) at the centre. In terms of policy, human security is a foreign policy issue only to the extent that it relates to Taiwan's efforts to join the World Health Organization. Kuo (2010) suggests that Taiwan learn from Japan's approach to human security as a "policy tool" (政策工具) to expand Taiwan's “international space” (外交空間) in the face of Chinese pressure, and thereby "the interests of Taiwan people can be more protected by the international system."

Much of the difference that Job and Evans identify can be understood as a difference in interests rather than beliefs. Like Korea and unlike Japan, Taiwan has no need to rebrand itself as security actor. Taiwan's international isolation and threat from China (which it faces with no formal US security guarantee - unlike Japan and Korea), means it is all but immune from being accused of "not pulling its weight" in terms of security. Taiwan faces no pressure to support US military actions or UN peacekeeping. On the contrary, it is barred from participation. Also, unlike Korea, it has no North Korean human security disaster on its border.

But to the extent that human security is a useful tool within this different context, Taiwan applies it much like Japan and Korea. Most notably, human 
security serves as a label for NTS threats related to globalisation that require regional collaboration. This is Job and Evan's (2008: 365) "third characteristic feature" of Northeast Asian human security, where "the threats are "nontraditional' security phenomena and their referent is the community, [while] the modalities of response are those of the traditional security paradigm."

Like Korea after MERS, the Taiwan government has used human security to signal a committed, whole of government approach to a problem that requires transnational cooperation. This can be seen in Vice President Annette Lu response to SARS (Presidential Office 2003a). Where transnational cooperation is not an issue, the traditional lexicon is preferred. Most notably, following public criticism of the Ma Ying-jeou administration's response to Typhoon Morakot disaster, the president and the Ministry of National Defense announced that disaster prevention and relief would be the military's "core mission" (China Times 2009).

In keeping with Japan and Korea, Taiwan has re-labelled existing ODA activities as Human Security activities. The 2009 white paper summary vaguely states that the third goal of Taiwan's ODA is "safeguarding human security," listing a series of threats without making any attempt to explain how its ODA addresses these (see MOFA (Taiwan) 2009a).

Again, like Japan and Korea, Taiwan sees human security as a tool to influence other countries. The authors of report commissioned by the National Development Council, Zhou et al. (2015), perceive that human security has allowed the Nordic countries, Canada, Japan and other countries to "expand" their foreign relations. The authors see Taiwan's "comparative advantage" deriving from Taiwan's successful development. Aid to its allies can therefore usefully become "the core value of Taiwan's international image." Taiwanese scholar Lin (2003) argues it is a way for Taiwan to follow the example of other countries in creating an international niche.

Taiwan participates in human security activities and discourse as means to maintain its profile within APEC, perhaps the most important international organisations to which Taiwan belongs. For example, in a speech ahead of the APEC meeting in 2003, President Chen Shui-bian stated that Taiwan has an obligation to promote human security commensurate with its important global role, and must highlight this role in order to develop international cooperation (Presidential Office 2004).

In addition, activities at APEC such as contributing US\$700,000 in human security funding and initiation of a Human Security Sub Fund (MOFA (Taiwan) 2015) can be seen, at least in part, as participating in a process which is more important to Taiwan's security than the particular outcomes. 
A unique and important feature of Taiwan's use of human security is to highlight the unfairness of its continuing international marginalisation due to Chinese pressure. For example, in 2003 President Chen argued that:

Taiwan, as a member of the international community, eager to start the new century by making a more positive contribution to the human security of the international community, does not want the absence of cooperation. However, Taiwan's active participation in international processes is often opposed by China for political reasons. China's political stance and methods to exclude Taiwan definitely do not help humanity face the current "transnational", "networking" security threats (Presidential Office 2003b). ${ }^{4}$

This argument carries considerable force (see e.g., Job and Evans 2008: 370).

However, at the same time, the sovereignty deemphasising aspect of the human security discourse can be used to pressure Taiwan to put aside sovereignty and find pragmatic solutions as a way to mitigate these risks (see e.g., Job and Evans 2008: 370). Hence, this conceptualisation of human security as transnational non-traditional security problems can be a rhetorical device to argue for change to the status quo of Taiwan's international marginalisation. Or, it can be used to find ways to technically manage the problems caused by this China-imposed marginalisation without addressing the isolation itself, thereby further cementing the marginalisation of the Taiwan state. Indeed, the malleability of the human security discourse means China is even able to frame its unification policy (backed by an overt threat of force) as a human security policy. The Chinese government does this through connecting the "human security challenge" of terrorism to two other "evil forces," religious extremism and separatism (Breslin 2015: 257). Breslin (2015: 257) notes that this makes a war over Taiwan independence a Human Security issue in China.

Turning to the domestic side, there are also significant parallels with Japan and South Korea. The human security of Taiwan's nationals has made remarkable progress in recent decades. Taiwan ranks with Japan and Korea as among the wealthiest and freest countries in the world. This is in stark contrast to the other main Northeast Asian countries, China and North Korea, which rank among the very worst in the world in terms of freedom and representation (Freedom House 2017; Reporters without Borders 2017; World Bank 2017). However, protection for migrants and workers and the impact of its deep water fishing industry on the human security of non-Taiwanese has been strongly criticised (McKinnel, Chiao and Lee 2016; Henley 2016). ${ }^{5}$ 


\section{DISCUSSION: HUMAN SECURITY IN EAST ASIA}

The cases of Japan, Korea and Taiwan demonstrate the pitfalls of treating human security straightforwardly as a norm that drives behaviour. In reality, other domestic norms can, and often do, drive an instrumental use of human security. So Evans (2004: 270) claims that the "norms of human security have made inroads in the established mind-sets of [East Asian] governments" is potentially truer in reverse; it is the established mind-sets of governments that have made inroads into the norms of human security. Different countries interpret human security differently due to their divergent historical experiences and domestic politics (Lam 2006: 146). So as Curley (2012: 530-531) notes, seeing human security as influencing Japan is too simplistic. The human security agenda Japan has pursued is one consistent with its wider foreign policy and bureaucratic imperatives.

Moreover, while Song (2014b: 6) is correct in claiming that Japan initiated the Asian approach to human security, in the cases of Korea and Taiwan this influence has potentially been more as a policy model than as a socialising agent of a new human security norm. Just as Japan's definition of human security promotes a leading role for Japan (Lam 2006: 146), it is also seen as beneficial to the influence of Korea and Taiwan in those countries.

A look at China's approach to human security helps illuminate these issues. East Asian democracies have emphasised human security more than the autocracies (Peou 2008). However, autocratic China has also drawn on Japan as a model of how to manage the human security discourse. There are Chinese scholars who see the human security discourse as a Western attempt to impose liberal preferences on China. But for other scholars, Japanese conceptions of human security provided an ambiguity that allows Chinese analysts to focus on socio-economic issues and avoid problematic political issues. In this way, as with other concepts such as human rights, nationalism, legitimacy and sovereignty that have entered China from the West and become naturalised to Chinese discourses and thinking, human security is being "nationalised" to Chinese conditions. The result is "to expand the understanding of what might constitute [human security] (and how it should be guaranteed) so far that the concept becomes all but pointless and redundant. And in many respects, this is the whole point of the exercise (for some at least)" (Breslin 2015: 243-245). Japan, too, "nationalised" human security to make it fit for Japanese purposes. The strategic culture of comprehensive security is important in determining how this purpose is conceived. And this Japanese disarming of the term and 
concurrent instrumentalisation facilitated Chinese efforts to disarm it even further.

This view of comprehensive security as the mind-set and human security as the instrument has several important implications for our understanding of the human security discourse. First, it is not very helpful to delineate an "Asian version" of human security. Kivimaki's (2014) discussion is representative of this problem. He identifies the five elements of the "Asian version" of human security as follows (Kivimaki 2014: 78-79):

1. Focused on the survival and well-being concerns of human beings as individuals or as a humanity (as opposed to a state);

2. Relevant threats are not only national, but transnational. Unlike traditional threats, sources of threats are not always an intentional agent (e.g., a virus). Or threats take a form that are rarely negotiated with, like criminals;

3. Threats may be of a novel kind;

4. The focus is on "other-help," as opposed to the self-help of traditional security;

5. Non-military responses are emphasised; most importantly, development.

All of these elements are visible in how Japan, Korea and Taiwan "do" human security. However, more interesting than what they do, is why. Kivimaki's (2014: 79-80) explanation of this ideational driver is worth quoting at length:

[For] some (mostly Western) theorists, the focus on human beings replaces the focus on national security while for others (mostly East Asian scholars), national security is instrumental to human security. The role of the state as a threat to or an instrument of human security is a fundamental alternative ontological premise of human security.... In the East Asian debate on human security, the instrumentalist concept is the mainstream one. According to this view, states are instruments (but not the only ones) of human security and thus national security is also important for human security.

By aggregating "East Asia," Kivimaki is conflating the views of the potential interveners and intervenees in a way that is not done for the "West." Southeast Asian elites have attempted to control the human security discourse, fearing its potential to undermine their legitimacy or the actions of external actors to address human rights abuses (Curley 2012: 532). Except in areas such as migrant protection mentioned above, international pressure over human rights is significantly less of an issue for Japan, Korea and Taiwan than it is for Southeast Asian governments. As Nishikawa (2009: 231) notes, Southeast 
Asian policymakers see human security as compatible with state security to the extent that state security generates human security. But there is tension between the two, and state violence at the expense of human security is likely to continue until this is reconciled.

True, emphasis on "freedom from want," through "good governance" supports the role of a strong state (Howe 2013). However, rather than principle or development theory, what matters more is the benefit Northeast Asian officials see accruing to their state and its citizens through provisioning friendly support to Southeast Asian governments. The shared belief in the importance of the state is coincidental and somewhat meaningless in terms of East-West dichotomies. Western governments also see the state as critically important. Indeed, much of the rationale for the human security discourse is precisely this problem of what to do when a government is not fulfilling its indispensable role. Furthermore, Northeast Asian governments' cognisance of the important role of the state does not drive them to better extend state protections to migrants. Rather, at least in part because they do not prioritise such protections (and indeed in part see a lack of protections for migrants as beneficial to their national economic vitality and the social wellbeing and cohesion of their citizens), they withhold some of those resources which they extend to their own nationals.

\section{CONCLUSION}

In this paper, I have argued that due to similar beliefs, histories and interests, Japan, Korea and Taiwan share considerable commonalities in their respective approaches to human security. In particular, they each adopt an instrumental approach to the human security discourse aimed at enhancing their comprehensive security.

It should not be a surprise that these three countries have shied away from the more challenging aspects or interpretations of human security. All of the reasons that Curley (2012: 537) predicts it unlikely the "human security agenda will be a priority in regional dialogue" involve Japan and/or Korea. Curley neglects Taiwan, but its security environment is at least as perilous. In such a situation it is understandable that policy makers make the most of the tools at their disposal while continuing to prioritise their own national security.

However, this instrumental approach is not without costs. HowardHassmann (2012: 88) persuasively warns that subsuming human rights under human security can undermine citizens struggling for their rights against their 
own states. Nevertheless, the important contribution of human security in shifting the focus away from protecting states to protecting individual human beings should not be overlooked (Alkire 2004: 359-360). In contrast to the top-down traditional view of security, human security is a bottom-up concept that prioritises people and their well-being (Edström 2003: 211-212). And as Job and Evans (2008: 359) note, human security's fundamental premise - that the safety and well-being of civilian populations should be the priority-has been increasingly accepted in the region.

Japan, Korea and Taiwan should embrace and foster this fundamental shift in focus. All three countries live in a dangerous neighbourhood, and face the threat of large scale warfare to an extent much greater than most other developed countries. It is in these countries' interests that the human security discourse continues to contribute to making nationalistic and revanchist wars and threats unacceptable. This long-term view should trump short term concerns to maintain traditional elite-led, nationalistic comprehensive security policies.

\section{ACKNOWLEDGEMENTS}

This work was supported by Hankuk University of Foreign Studies Research Fund.

\section{NOTES}

* Joel Atkinson is an Associate Professor with the Department of Chinese Studies at Hankuk University of Foreign Studies' Graduate School of International and Area Studies (GSIAS) in Seoul, where he researches and teaches East Asian international relations. He received his $\mathrm{PhD}$ from Monash University in Melbourne, Australia. He is the author of Australia and Taiwan: Bilateral Relations, China, the United States, and the South Pacific (Leiden \& Boston: Brill). His research has been published in Development Policy Review, The Pacific Review, Pacific Affairs, the Australian Journal of International Affairs, and elsewhere.

1 Read as füguó qiángbing in Chinese, fukokukyōhei in Japanese, and bugug gangbyeong (부국 강병) in Korean.

2 Lam Peng Er (2006: 143-144) makes a stronger case for Japan's contribution: “Tokyo's provision of political good offices to consolidate peace and assist in the reconstruction of certain civil war-shattered societies in Southeast Asia can indeed be interpreted as falling within the rubric of human security because thousands of lives and their betterment are at stake." 
3 Kuo Kuo-wen (郭國文) is also known as Robert Kuo. He was a Democratic Progressive Party (DPP) Central Executive Committee member at the time. He was a Tainan City councillor and Tainan branch director for the DPP, and previously secretary general of the Taiwan Labor Front (台灣勞工陣線). He is now deputy labour minister in the Tsai Ying-wen administration.

4 Translation by the author. Original Chinese is “台灣作為國際社會的成員, 渴望在 新世紀開始之際, 對國際社會之人類安全, 做出更積極的貢獻, 不願在國際社 會合作中缺席。然而, 台灣在積極參與國際的過程中, 經常由於中國基於政治 理由, 反對台灣的參與。中國這種基於政治主張, 排除台灣的作法, 並無助於 當前人類在面對「跨國化」、「網絡化」安全威脅問題的解決.”

5 For a comparable international critique for Korea see Amnesty International (2014).

\section{REFERENCES}

Acharya, A. 2001. Human security: East versus West. International Journal 56 (3): $442-$ 460, https://doi.org/10.1177/002070200105600304.

Akami, T. 2006. In the name of the people: Welfare and societal security in modern Japan and beyond. Asian Perspective 30 (1): 157-190.

Allison, R. 2017. Russia and the post-2014 international legal order: Revisionism and realpolitik. International Affairs 93 (3): 519-543, https://doi.org/10.1093/ia/iix061.

Alkire, S. 2004. A vital core that must be treated with the same gravitas as traditional security threats. Security Dialogue 35 (3): 359-360, https://doi.org/10.1177/09670 1060403500317.

Amnesty International. 2014. Bitter harvest: Exploitation and forced labour of migrant agricultural workers in South Korea (ASA 25/004/2014). https:/www.amnesty.org/ en/documents/asa25/004/2014/en/ (accessed 25 June 2017).

Atkinson, J. 2017. Comparing Taiwan's foreign aid to Japan, South Korea and DAC. Journal of the Asia Pacific Economy 22 (2): 253-272, https://doi.org/10.1080/135 47860.2016.1245926.

Berkowitz, R. 2011. Assassinating justly: Reflections on justice and revenge in the Osama Bin Laden Killing. Law, Culture and the Humanities 7 (3): 346-351, https://doi/ org/10.1177/1743872111418172.

Bowers, I. 2014. Korean approaches to peace support and stability operations. In AsiaPacific nations in international peace support and stability operations, ed. Aoi, C. and Heng, Y.-K., 87-111. New York: Palgrave Macmillan US, https://doi. org/10.1057/9781137366955.0009.

Breslin, S. 2015. Debating human security in China: Towards discursive power? Journal of Contemporary Asia 45 (2): 243-265, https://doi.org/10.1080/00472336.2014.90 7926.

Breslin, S. and Christou., G. 2015. Has the human security agenda come of age? Definitions, discourses and debates. Contemporary Politics 21 (1): 1-10, https://doi.org/10.108 0/13569775.2014.993904.

Bridges, B. 1992. South Korea and the Gulf crisis. The Pacific Review 5 (2): 141-148, doi:10.1080/09512749208718968 
Brown, S. 2016. From Ottawa to Kandahar and back: The Securitization of Canadian foreign aid. In The securitization of foreign aid, ed. Brown, S. Grävingholt, J., 113-137. Basingstoke, UK: Palgrave Macmillan, https://doi.org/10.1007/978-1137-56882-3_6.

Carvalho, P. A. R. and Potter, D. 2016. Peacebuilding and the 'human securitization' of Japan's foreign aid. In The Securitization of Foreign Aid, ed. Brown, S. and Grävingholt, J., 85-112. Basingstoke, UK: Palgrave Macmillan, https://doi. org/10.1007/978-1-137-56882-3_5.

Ch'en, H. P. and Kowashi, I. 1984. The principles of reform. In Japan in transition: Thought and action in the Meiji Era, 1868-1912, ed. Conroy, H. et al., 229-232. Canbury, NJ: Associated University Presses.

China Times. 2009. Military's core mission: Rescue and relief. Taiwan Today, 4 September. http://www.taiwantoday.tw/ct.asp?xItem $=62509 \&$ CtNode $=436$ (accessed on 1 July 2017)

Cho, Y. C. 2008. South Korea's security practice from 1945 to 1998 : A critical review. The Journal of Peace Studies 9 (4): 143-176.

Curley, M. 2012. Human security's future in regional cooperation and governance? Australian Journal of International Affairs 66 (5): 527-541, https://doi.org/10.108 0/10357718.2011.570242.

Deng, Y. and Wang, F.-L. 1999. In the eyes of the dragon: China views the world. Lanham and Oxford: Rowman \& Littlefield Publishers.

Edström, B. 2003. Japan's foreign policy and human security. Japan Forum 15 (2): 209225. https://doi.org/10.1080/0955580032000108397.

Evans, P. M. 2004. Human security and East Asia: In the beginning. Journal of East Asian Studies 4 (2): 263-284, https://doi.org/10.1017/S1598240800001831.

Freedom House. 2017. Freedom in the world 2017. Online report. https://freedomhouse. org/report/freedom-world/freedom-world-2017 (accessed 1 July 2017).

Fukushima, A. 2008. East vs. West? Debate and convergence on human security. In Human security in East Asia, ed. Peou, S., 46-60. New York: Routledge.

Gilson, J. and Purvis, P. 2003. Japan's pursuit of human security: Humanitarian agenda or political pragmatism? Japan Forum 15 (2): 193-207, https://doi.org/10.1080/0955 580032000108388

Glenn, J. 2009. Realism versus strategic culture: Competition and collaboration? International Studies Review 11 (3), 523-551, https://doi.org/10.1111/j.14682486.2009.00872.x.

Grundy, J. et al. 2012. The responsibility to protect: Inequities in international aid flows to Myanmar and the democratic people's Republic of Korea and their impact on maternal and child health. Asian Studies Review 36 (2), 171-187. doi:10.1080/103 57823.2012.685449

Guan, B. T. C. 2012. Introduction: Human security development and the future of East Asia. In Human security: Securing East Asia's Future, ed. Teh, B. C. G., 1-14. Amsterdam: Springer, https://doi.org/10.1007/978-94-007-1799-2_0.

Healy, D. 1970. US Expansionism: The imperialist urge in the 1890s. Madison: University of Wisconsin Press. 
Henley, J. 2016. Death, abuse, exploitation: Taiwan's migrant worker shame. South China Morning Post Magazine, 6 October. http://www.scmp.com/magazines/postmagazine/long-reads/article/2025340/death-abuse-exploitation-taiwans-migrantworker (accessed 20 November 2016).

Hershkoff, H. 2002. Positive rights and the evolution of state constitutions. Rutgers Law Journal 33 (4): 799-834.

Hill, C. 2003. The changing politics of foreign policy. New York: Palgrave MacMillan.

Ho, S. 2008. Japan's human security policy: A critical review of its limits and failures. Japanese Studies 28 (1), 101-112. https://doi.org/10.1080/10371390801939120

Howard-Hassmann, R. E. 2012. Human security: Undermining human rights? Human Rights Quarterly 34 (1), 88-112, https://doi.org/10.1353/hrq.2012.0004.

Howe, B. 2013. The protection and promotion of human security in East Asia. London: Palgrave Macmillan. https://doi.org/10.1057/9781137293657.

Hughes, C. W. and Krauss, E. S. 2007. Japan's new security agenda. Survival 49 (2), $157-$ 176. https://doi.org/10.1080/00396330701437850

Hughes, C. 2015. Japan's foreign and security policy under the "Abe doctrine": New dynamism or new dead end? Basingstoke, UK: Palgrave Macmillan.

Job, B. L. and Evans, P. M. 2008. Human security and Northeast Asia: Seeds germinating on hard ground. In Institutionalizing Northeast Asia: Regional steps towards global governance, ed. Timmermann, M. and Tsuchiyama, J., 359-376. Tokyo and New York: United Nations University Press.

Johnston, A. I. 1995. Thinking about strategic culture. International Security 19 (4), 32-64, https://doi.org/10.2307/2539119.

Kaji, M. 2015. Why human security, why Japan? In Human security, changing states and global responses: Institutions and practices, ed. Bae, S. and Maruyama, M., 48-66. Abingdon, Oxon: Routledge.

Kang, S.-j. 2008. The new government's contribution diplomacy: Tasks and prospect of ODA. Korea Focus, 4 April.

Kawai, M. and Takagi, S. 2004. Japan's official development assistance: Recent issues and future directions. Journal of International Development 16 (2), 255-280. https:// doi.org/10.1002/jid.1074

Kim, E. M., Bae, S. Y. and Shin, J. H. 2015. Human security in practice: The case of South Korea (JICA-RI Working Paper 93). http://jica-ri.jica.go.jp/publication/assets/ JICA-RI\%20WP\%20No.93.pdf (accessed 12 April 2016)

Kim, J. 2014. Strategic culture of the Republic of Korea. Contemporary Security Policy 35 (2), 270-289, https://doi.org/10.1080/13523260.2014.927675

Kim, S.-T. and Seddon, D. 2005. ODA policy and practice: Japan and the Republic of Korea. In Japan's foreign aid: Old continuities and new directions, ed. Arase, D., 152-190. New York: Routledge.

Kioko, B. 2011. The right of intervention under the African Union's Constitutive Act: From non-interference to non-intervention. Revue Internationale de la Croix-Rouge (International Review of the Red Cross) 85 (852): 807-826, https://doi.org/10.1017/ S0035336100179948.

Kivimaki, T. 2014. Can the pragmatic East Asian approach to human security offer a way for the deepening of the long peace of East Asia? Journal of Human Security 10 (1): 76-88, https://doi.org/10.12924/johs2014.10010076. 
Krasner, S. D. 1999. Sovereignty: Organized hypocrisy. Princeton: Princeton University Press, https://doi.org/10.1515/9781400823260.

Kuo, K. (郭國文). 2010. 2010年世界公民人權高峰會 (2010 World summit on human rights for world citizens: 日本-人類安全-政策及其對台灣的啟示.) Association of World Citizens in Taiwan. http://www.worldcitizens.org.tw/awc2010/ch/F/F_d_ page.php?pid=9513.

Lam, P. E. 2006. Japan's human security role in Southeast Asia. Contemporary Southeast Asia 28 (1): 141-159, https://doi.org/10.1353/csa.2006.0002.

Lee, S.-J. 2015. South Korea should take measures to support democracy (EAI column June). http://www.eai.or.kr/type/panelView.asp?bytag=p\&code=eng report\&idx $=13861 \&$ page $=4$ (accessed 17 April 2016)

Lin, Z-X. 林宗憲. 2003. 中等國家之國際參與：加拿大外交政策及其對台灣之敔示 (The interntaional involvment of middle powers: The implications of Canadian foreign policy for Taiwan). 全球政治評論 4 (10月 ):117-134.

McKinnel, T., J. Y. Chiao, and Lee, D. S. 2016. Made in Taiwan: Government failure and illegal, abusive and criminal fisheries. Taipei: Greenpeace East Asia Taipei office. http://www.greenpeace.org/international/Global/international/publications/ oceans/2016/Taiwan-Tuna-Rpt-2016.pdf (accessed 1 July 2017).

Meyer, C. O. 2006. The quest for a European strategic culture. London: Springer. https:// doi.org/10.1057/9780230598218, https://doi.org/10.1057/9780230598218.

MOFA (Korea). 2008. 인간안보의 중요성과 논의 동향. http://www.mofa.go.kr/ webmodule/htsboard/template/read/korboardread.jsp?typeID=6\&boardid $=102 \&$ seqno $=312789 \& \mathrm{c}=\& \mathrm{t}=\&$ pagenum $=1 \&$ tableName $=$ TYPE DATABOARD $\& \mathrm{pc}=\& \mathrm{dc}=\& w \mathrm{c}=\& l u=\& v u=\& i u=\& d u=($ accessed 13 April 2016)

MOFA (Taiwan). 2009a. Summary of Taiwan's foreign aid policy white paper. http://www. taiwanembassy.org/be/ct.asp?xItem $=90636 \&$ ctNode $=463 \& \mathrm{mp}=102$ (accessed 12 April 2016)

MOFA (Taiwan). 2009b. White paper on foreign aid policy: Partnerships for progress and sustainable development. http://www.mofa.gov.tw/public/ Attachment/991021195571.pdf (accessed 22 July 2010)

MOFA (Taiwan). 2015. Republic of China donates US\$700,000 to help APEC boost human security, capacity building, and regional economic integration. http://www.mofa.gov. tw/en/News_Content.aspx?n=1EADDCFD4C6EC567\&s=EB36EB4897B5C0FB (accessed 12 April 2016)

Moore, A. W. 2013. Writing war: Soldiers record the Japanese empire. Cambridge: Harvard University Press, https://doi.org/10.4159/harvard.9780674075399.

Moore, G. J. 2013. Constructing cooperation in Northeast Asia: Historical northeast Asian dyadic cultures and the potential for greater regional cooperation. Journal of Contemporary China 22 (83), 887-904, https://doi.org/10.1080/10670564.2013.7 82132

Moran, J. 1998. The role of the security services in democratization: An analysis of South Korea's agency for national security planning. Intelligence and National Security, 13 (4), 1-32. https://doi.org/10.1080/02684529808432503

Nishikawa, Y. 2009. Human security in Southeast Asia: Viable solution or empty slogan? Security Dialogue 40 (2): 213-236, https://doi.org/10.1177/0967010609103088. 
Oros, A. 2017. Japan's security renaissance: New policies and politics for the twenty-first century. New York: Columbia University Press, https://doi.org/10.7312/oros17260.

Paris, R. 2001. Human security: Paradigm shift or hot air? International Security, 26 (2), 87-102. https://doi.org/10.1162/016228801753191141.

Peou, S. 2008. Critical challenges for globalism in human security studies. In Human security in East Asia, ed. Peou, S., 13-28. Routledge.

Presidential Office. 2003a. 副總統召開「因應後SARS 時代圓桌論壇」討論「人類安 全」. http://www.president.gov.tw/Default.aspx?tabid=131\&itemid=322\&rmid= $514 \&$ sort $=0 \&$ order $=1$ (accessed 18 April 2016)

Presidential Office. 2003b. 總統出席二 O O 三卡拉漢國際年會. http://www.president. gov.tw/ Default.aspx?tabid=131\&itemid=8707 (accessed 18 April 2016)

Presidential Office. 2004. 總統主持 A P E C 高層會議. http://www.president.gov.tw/ DesktopModules/Bulletins/FriendPrint.aspx?itemid=3132\&citid=105 (accessed 18 April 2016)

Reporters without Borders. 2017. 2017 World press freedom index. https://rsf.org/en/ ranking (accessed 1 July 2017).

Rhyu, S.-y. and Lee, S. 2006. Changing dynamics in Korea-Japan economic relations: Policy ideas and development strategies. Asian Survey 46 (2), 195-214, https://doi. org/10.1525/as.2006.46.2.195

Samuels, R. J. 2007. Securing Japan: Tokyo's grand strategy and the future of East Asia. New York: Cornell University Press.

Sato, J. 2013. Domestic functions of economic cooperation: Japan's evolution as a donor in the 1950s. In The rise of Asian donors: Japan's impact on the evolution of emerging donors, ed. Sato, J. and Shimomura, Y., 11-28. Oxon, UK: Routledge.

Schell, O. and Delury, J. 2013. Wealth and power: China's long march to the twenty-first century. Hachette, UK: Random House.

Sheldon, G. 2002. Saving for 'My own good and the good of the nation': Economic nationalism in modern Japan. In Nation and nationalism in Japan, ed. Wilson, S., 97-114. Abingdon, Oxon: RoutledgeCurzon.

Snyder, J. 1977. The Soviet strategic culture: Implications for nuclear options. Santa Monica, CA: Rand.

Soderberg, M. 2005. Swedish perceptions of Japanese ODA. In Japan's foreign aid: Old continuities and new directions, ed. Arase, D., 81-94 . New York Routledge.

Song, J. 2014a. Complex human security in North Korean irregular migration. In Irregular migration and human security in East Asia, ed. Song, J. and Coo, A. D. B., 137154. London: Routledge.

Song, J. 2014b. Introduction. In Irregular migration and human security in East Asia, ed. Song, J. and Coo, A. D. B., 1-20. London: Routledge.

Suhrke, A. 1999. Human security and the interests of states. Security Dialogue 30 (3): 265-276. https://doi.org/10.1177/0967010699030003002.

Takay, S. 2014. Making irregular migrants insecure in Japan. In Irregular migration and human security in East Asia, ed. Song, J. and Coo, A. D. B., 23-37. London: Routledge. 
Tan, W-E 譚偉恩. 2016. 人類安全的虛偽性: 以中型國家在治理人口販運上的實踐 為例 (The hypocrisy of human security: The study on the governance of human trafficking in the middle powers). 國際與公共事務 (International and Public Affairs) 4 (7): 33-66.

United Nations 2001. Definitions of human security. https://www.gdrc.org/sustdev/husec/ Definitions.pdf (accessed 20 Jan 2012).

World Bank. 2017. The worldwide governance indicators. http://info.worldbank.org/ governance/wgi/\#home (accessed 1 July 2017).

Yoshihara, T. and Holmes, J. R. 2006. Japanese maritime thought: If not Mahan, who? Naval College Review 59 (3): 23-51, https://doi.org/10.21236/ADA520373.

Zhou, Z. et al. 2015. 我國長期性國際參與策略之研究 (委託研究

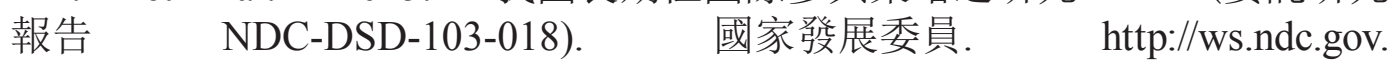
tw/Download.ashx? u=L z AwMS9h ZG1pbmlzdHJhdG9yLzEwL 3 J 1 b G Z p b G UvN T Y 0 N C 8 y N j c 4 L z A w N j I 3 N z g u c G R m \& n =5oiR5ZyL6ZW35pyf5oCn5ZyL6Zqb5Y\%2BD6IiH562W55W15LmL56CU5 6m2LnBkZg\%3D\%3D\&icon=..pdf (accessed 15 June 2017). 